\title{
RANCANG BANGUN MESIN PENGADUK PEKAN TERNAK
}

\author{
Beni Junaedi Hilimi \\ Program Studi Mesin dan Peralatan Pertanian \\ Politeknik Gorontalo
}

\begin{abstract}
ABSTRAK
Pakan adalah bahan makanan tunggal atau campuran, baik yang diolah maupun yang tidak diolah, yang diberikan kepada hewan untuk kelangsungan hidup, berproduksi, dan berkembang biak.. Untuk menunjang tujuan tersebut dengan merancang suatu mesin pengaduk untuk membantu proses pencampuran pakan ternak sapi yang lebih cepat dan efisien. Tujuan utama saya dalam menciptakan inovasi teknologi yang sedang berkembang saat ini supaya hasil yang didapat lebih efektif dan berkualitas. Metode penelitian yang digunakan dalam penelitian merancang suatu mesin pengaduk untuk membantu proses pencampuran pakan ternak sapi ini adalah empirik, yaitu pengamatan dilapangan (observasi). Tujuan peneliti merancang suatu mesin pengaduk pakan ternak, mengetahui system kerja pengaduk pakan. Pengaduk pakan ternak dirancang menggabungkan beberapa komponen yakni mata pisau, poros as, mesin 1,5 $\mathrm{Hp}$, dan bearing. Hasil uji coba pada pengujian $12.45 \mathrm{Rpm} / \mathrm{kg}$ didapatkan rata-rata $2.45 \mathrm{Rpm} / \mathrm{kg}$, rata-rata hasil pengujian $22.98 \mathrm{Rpm} / \mathrm{kg}$, rata-rata hasil pengujian 3 dengan kapasitas $3.42 \mathrm{Rpm} / \mathrm{kg}$.
\end{abstract}

Kata Kunci : Pengaduk, tabung, mata pisau, dan ternak.

\section{DESIGN AND DEVELOPMENT OF ANIMAL WEEKENDS MACHINE}

\begin{abstract}
Feed is a single or mixed food ingredient, both processed and unprocessed, which is given to animals for survival, production and breeding. To support this goal by designing a stirring machine to help the process of mixing cattle feed faster and efficient. My main goal is to create technological innovations that are currently developing so that the results obtained are more effective and quality. The research method used in the study of designing a stirrer to help the process of mixing cattle feed is empirical, namely observation in the field (observation). The purpose of the researchers designing a animal feed mixer, knowing the work system of feed mixers. Animal feed mixer is designed to combine several components, namely the blade, axle, $1.5 \mathrm{hp}$, and bearing. The results of the trial at test $12.45 \mathrm{Rp}$. / Kg obtained an average of $2.45 \mathrm{Rpm} / \mathrm{kg}$, the average test results $22.98 \mathrm{Rpm} / \mathrm{kg}$, the average test results 3 with a capacity of $3.42 \mathrm{Rpm} / \mathrm{kg}$.
\end{abstract}

Key Words : Stirrers, tubes, blades and livestock. 


\section{PENDAHULUAN}

Perkembangan bidang peternakan di Indonesia sudah sangat pesat. Beberapa jenis hewan ternak sudah dibudidayakan secara baik dan optimal. Permasalahan yang timbul adalah proses pengadukan pakan ternak menggunakan cara manual atau tenaga manusia yang kurang efektif. Hal tersebut diketahui dari hasil pengadukan pakan dalam jumlah yang relatif banyak memerlukan waktu pengadukan yang relatif lama sehingga pemenuhan kebutuhan pakan untuk hewan ternak dalam jumlah banyak kurang maksimal. Selain proses pengadukan masalah yang sering timbul adalah hasil dari pengadukan dan pencampuran pakan yang kurang merata karena pengadukan pakan dalam jumlah banyak dengan menggunakan cara manual. Oleh karena itu demi keoptimalan pemenuhan pakan ternak saya membuat alat pengaduk pakan ternak yang berfungsi memproses pengadukan dan pencampuran pakan supaya lebih merata dengan waktu yang relatif singkat. (Utomo, 2011)

Pakan adalah bahan makanan tunggal atau campuran, baik yang diolah maupun yang tidak diolah, yang diberikan kepada hewan untuk kelangsungan hidup, berproduksi, dan berkembang biak. Pakan merupakan faktor utama dalam keberhasilan usaha pengembangan peternakan disamping faktor bibit dan tatalaksana. Pakan yang berkualitas akan sangat mendukung peningkatan produksi maupun reproduksi ternak. (Anggorodi, 1985)

Di Indonesia khususnya di Provinsi Gorontalo memiliki tanaman pangan yang sangat melimpah. Tanaman pangan tersebut adalah Sekam padi, Jerami jagung, Daun ubi kayu dan rumput gajah. Kebiasaan yang sering dilakukan oleh masyarakat adalah pengambilan pakan ternak dilakukan dengan cara manual yang tidak diolah diberikan kepada hewan ternak. Hal inilah yang membawa dampak pada hewan ternak tidak akan meningkatkan produksi pakan ternak pada umumnya.

Tingginya produksi limbah tanaman pangan pada suatu daerah dipengaruhi oleh luas areal panen tanaman pangan yang tinggi khususnya areal panen padi sehingga menghasilkan jerami padi yang lebih banyak dan akhirnya berpengaruh kepada tingginya total produksi bahan kering limbah tanaman pangan (Syamsu, 2007).

Hambatan yang sering dialami adalah kualitas yang rendah, kurang disukai ternak, konversinya tidak mudah dan produksinya berfliktuasi. Makanan ternak haruslah tersedia sepanjang tahun dalam jumlah dan kualitas yang cukup, sedangkan lahan yang dikhususkan untuk produksi hijaun makanan ternak tidak selalu tersedia, kecuali adanya padang rumput alam dibeberapa daerah. Kekurangan bahan makanan ini sebenarnya dapat mencukupi dengan pengelolaan dan pemanfaatan limbah pertanian yang cukup melimpah. (Djayanegara, 1983)

\section{TINJAUAN PUSTAKA}

\section{Pakan Ternak}

Pakan atau makanan ternak adalah bahan yang dapat dimakan, dicerna dan dapat digunakan oleh ternak. Secara umum bahan makanan ternak adalah bahan yang dapat dimakan oleh ternak, tetapi tidak semua komponen dalam bahan makanan ternak tersebut dapat dicerna oleh ternak. Bahan makanan ternak mengandung zat makanan dan merupakan istilah umum, sedangkan komponen dalam bahan makanan ternak tersebut dapat digunakan oleh ternak disebut zat makanan. Selanjutnya Badan Standarisasi Nasional juga mendefinisikan bahan pakan adalah bahan-bahan hasil pertanian, perikanan, peternakan dan hasil 2ndustry yang mengandung zat gizi dan layak dipergunakan sebagai pakan, yang telah diolah maupun belum diolah. (Tillman, 1989).

\section{Limbah Tanaman Pangan}

Secara umum, pengertian dari pertanian adalah suatu kegiatan manusia yang meliputi pertanian tanaman pangan, perkebunan, kehutanan, holtikultura, peternakan dan perikanan. Sedangkan Pengertian tanaman pangan: segala jenis tanaman yang dapat menghasilkan karbohidrat dan protein (Rani, 2010).

Limbah pertanian dan agroindustri pertanian memiliki potensi yang cukup besar sebagai sumber pakan ternak ruminansia. Jenis limbah pertanian yang sering digunakan sebagai pakan ternak adalah sekam padi, jerami jagung, jerami kacang tanah, jerami kedelai, dan pucuk ubikayu (Djajanegara, 1999).

\section{Jenis Pakan Ternak}

Sekam Padi

Sekam padi adalah bagian terluar dari butir padi yang merupakan hasil samping saat proses 
penggilingan padi dilakukan. Sekitar 20\% dari bobot padi adalah sekam padi dan kurang lebih 15\% dari komposisi sekam padi adalah abu sekam yang selalu dihasilkan setiap kali sekam dibakar.

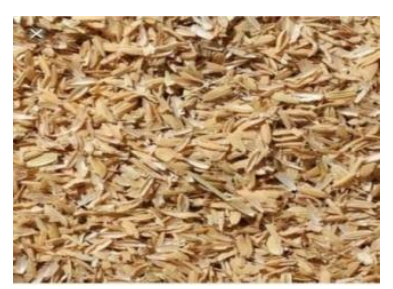

Gambar 2.1. Sekam padi (Harsono 2002)

Jerami Jagung

Jerami jagung merupakan limbah yang ditinggalkan setelah jagung dipanen yang berupa daun dan batang. Jerami padi sudah banyak digunakan sebagai pakan ternak terutama sebagai pengganti sumber serat atau mengganti $50 \%$ dari rumput dan hijauan tetapi jerami jagung memiliki kecernaan dan kadar protein yang rendah. Jerami jagung juga memiliki sifat yang voluminous. Jerami jagung merupakan bahan makanan yang memiliki kualitas yang rendah dan tidak akan mencukupi untuk kebutuhan ternak kecuali jika diberi tambahan suplemen pada pakannya. Kandungan bahan kering jerami jagung 28\%, protein $8,2 \%$ dan TDN $48 \%$.

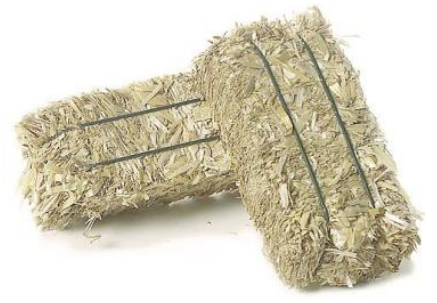

Gambar 2.2. Jerami Jagung (Sukria, 2009)

Daun Ubi Kayu

Daun Ubi kayu merupakan tanaman tropik yang potensial digunakan untuk ternak dan dapat menghasilkan biomassa sumber energi pada bagian umbi dan protein pada daun dalam jumlah besar. Dari 2,5-3 ton/ha hasil samping tanaman ubi kayu dapat menghasilkan tepung daun ubikayu sebanyak 600-800 kg/ha. Daun ubi kayu mengandung senyawa sianida yang bersifat racun, tinggi rendahnya kandungan sianida merupakan pembatas pemanfaatan daun ubi kayu. Daun ubi kayu mempunyai kandungan protein yang tinggi yaitu berkisar antara 16,7-39,9\% bahan kering dan hampir $85 \%$ dari fraksi protein kasar merupakan protein murni.

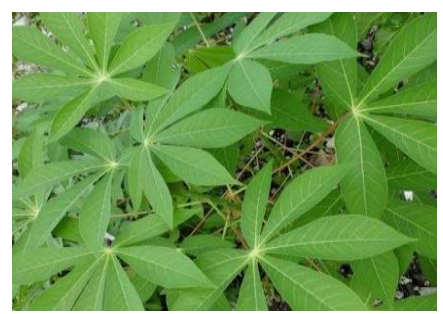

Gambar 2.3. Daun Ubi Kayu (Ahmad, 2010)

Rumput gajah

Rumput Gajah atau disebut juga rumput napier, merupakan salah satu jenis hijauan pakan ternak yang berkualitas dan disukai ternak. Rumput gajah dapat hidup diberbagai tempat, tahan lindungan, respon terhadap pemupukan, serta menghendaki tingkat kesuburan tanah yang tinggi. Rumput gajah tumbuh merumpun dengan perakaran serabut yang kompak, dan terus menghasilkan anakan apabila dipangkas secara teratur. pakan-ternak.

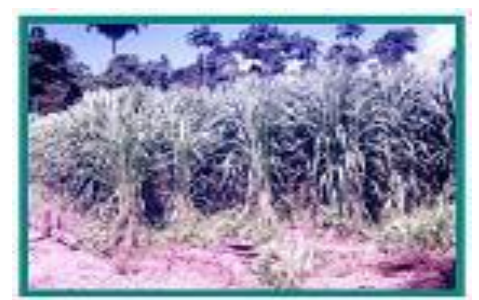

Gambar 2.4. Rumput Gajah (Sutan muda, 2008)

\section{Jenis Mesin Pengaduk Pakan Ternak Sebelumnya}

Jenis mesin pengaduk pakan ternak sebelumnya menggunakan dua tipe dengan cara vertikal dan horisontal yaitu sebagai berikut :

\section{Pengaduk Pakan Ternak Tipe Vertikal}

Vertical mixer biasanya digunakan pada pabrik kecil atau pada peternakan yang mencampur pakan sendiri. Alat pengaduk dapat berupa campuran screw tunggal dan ganda. Mixer vertikal merupakan alat penyampur bahan pakan yang memanfaatkan gaya gravitasi untuk menyampur bahan pakan. Pada bagian dalam alat mixer vertikal terdapat pipa yang berisi as berulir (screw) sehingga ketika berputar dapat mengangkat bahan pakan. Ujung atas pipa merupakan bagian yang terbuka sehingga ketika bahan pakan naik akan tersebar dan jatuh pada semua bagian dalam tabung penampung. 


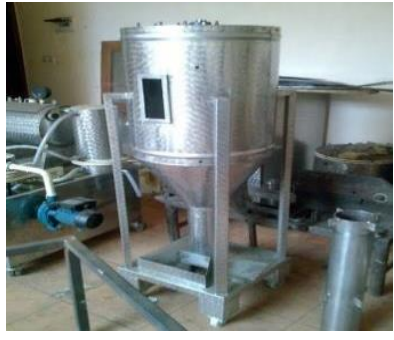

Gambar 2.5. Mixer Vertikal (Rekatehnikindo.2015).

\section{Pengaduk Pakan Ternak Tipe Horizontal}

Berbeda dengan mixer vertikal yang menggunakan bantuan gaya gravitasi, Mixer horisontal sepenuhnya memanfaatkan tenaga motor. Motor menggerakan screw (as) yang terpasang horisontal pada bagian tengah tabung dan memiliki pengaduk. Berputarnya screw (as) dan pengaduk akan menyebabkan perputaran bahan pakan dalam tabung dimana alur pengadukan menjadi berlawanan antara alur dalam dan luar. Urutan pemasukan bahan dalam mixer adalah bahan baku mayor, bahan baku minor, bahan adiktif, dan cairan. (Rekatehnikindo.2015).

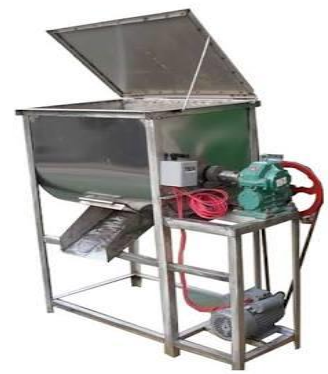

Gambar 2.6. Mixer Horizontal (Rekatehnikindo.2015)

\section{METODE PENELITIAN}

\section{Prosedur Penelitian mesin pengaduk pakan ternak}

Adapun tahapan modifikasi mesin pengaduk pakan ternak sebagai berikut:

Penelitian diawali dengan proses desain kemudian dilanjutkan dengan pembuatan alat pengaduk pakan ternak. Hasil pembuatan tersebut akan dilakukan pengujian pencampuran atau pengadukan pakan ternak dengan menggunakan putaran poros yaitu dengan cara horizontal agar hasil 4 jenis pakan ternak tersebut pengolahannya tercampur bagus. Selanjutnya akan dievaluasi kinerja mesin pengaduk pakan ternak tersebut terutama menghitung laju pengadukan pada pakan dan efesiensi dari mesin pengaduk pakan ternak tersebut.

\section{HASIL DAN PEMBAHASAN}

Pembuatan alat pengaduk pakan ternak ini dengan menggunakan prinsip pencampuran proses horizontal yang memiliki tinggi total $73 \mathrm{~cm}$, besar tabung silinder pencampuran Ø50. Alat pencampur pakan ternak dapat dilihat pada Gambar 4.1 sebagai berikut.

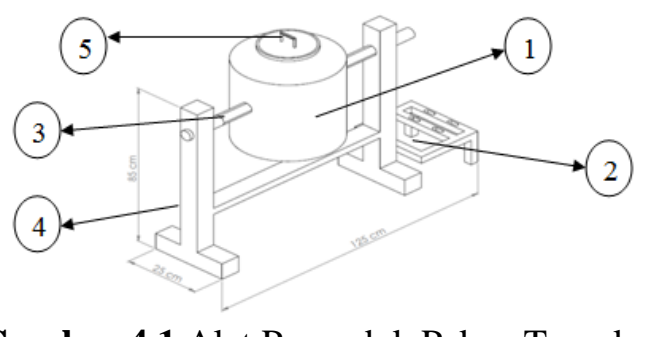

Gambar 4.1 Alat Pengaduk Pakan Ternak

Alat pengaduk pakan ternak ini menggunakan prinsip pengadukan poros horizontal yang dapat menghasilkan pakan ternak terutama ternak sapi dan kambing.

1. Tabung pengaduk

2. Rangka mesin pengaduk pakan

3. As pengaduk pakan

4. Rangka alat pengaduk pakan

5. Penutup

Pada mesin pengaduk pakan ternak terdapat komponen-komponen dan prinsip kerja alat. Komponen-komponen itu antara lain

1. Tabung pengaduk merupakan komponen utama pada mesin pengaduk pakan ternak, karena pada komponen ini berfungsi sebagai tempat terjadi proses pengadukan pakan.

2. Rangka utama merupakan komponen utama pada mesin pengaduk pakan ternak karena pada komponen ini berfungsi sebagai tumpuan dari komponenkomponen lain pada mesin tersebut.

3. Pengaduk pakan yang digunakan yaitu merupakan besi beton dan besi strip yang berfungsi sebagai pengadukan pakan dengan memanfaatkan putaran poros horizontal.

4. Pada mesin pengaduk pakan ternak hopper hanya memiliki satu, hopper yang berfungsi keluar masuknya bahan pakan, 
hopper pencampur pakan ternak memiliki ukuran Ø25. Penutup guna menahan keluarnya bahan pakan saat beroperasi sehingga bisa dibolak-balik tabung silinder pengaduk pakan.

\section{Analisis kinerja mesin pengaduk pakan}

Uji coba alat dilakukan selama 3 kali pengujian. Pada putaran pertama kecepatan putaran poros sebesar $750 \mathrm{rpm}$, putaran kedua kecepatan putaran poros sebesar $1000 \mathrm{rpm}$ dan putaran untuk ketiga putaran poros sebesar 1250 rpm, sementara untuk jumlah rata-rata bahan pakan sebanyak $8.5 \mathrm{~kg}$. hasil pengujian ditunjukan pada Tabel 4.1 sebagai berikut.

\begin{tabular}{|c|c|c|c|c|c|c|c|c|}
\hline $\begin{array}{c}\text { No } \\
\text { Percoba } \\
\text { an }\end{array}$ & $\begin{array}{c}\text { Putara } \\
\mathbf{n} \\
(\mathrm{Rpm})\end{array}$ & $\begin{array}{c}\text { Poro } \\
\text { s } \\
(\mathrm{Rp} \\
\mathrm{m})\end{array}$ & $\begin{array}{c}\text { Bera } \\
\text { t } \\
\text { seka } \\
\text { m } \\
\text { padi } \\
(\mathrm{kg})\end{array}$ & $\begin{array}{c}\text { Bera } \\
\mathbf{t} \\
\text { dau } \\
\mathrm{n} \\
\mathrm{ubi} \\
(\mathrm{kg})\end{array}$ & $\begin{array}{c}\text { Berat } \\
\text { rump } \\
\text { ut } \\
\text { gajah } \\
(\mathrm{kg})\end{array}$ & $\begin{array}{c}\text { Berat } \\
\text { jera } \\
\text { mi } \\
\text { jagun } \\
\mathrm{g}(\mathrm{kg})\end{array}$ & $\begin{array}{c}\text { Jumla } \\
\text { h } \\
\text { Rata- } \\
\text { rata } \\
\text { (kg) }\end{array}$ & $\begin{array}{c}\text { Efisien } \\
\text { si }\end{array}$ \\
\hline 1 & 2607 & 750 & 2.5 & 2 & 1 & 3 & 8.5 & 2.45 \\
\hline 2 & 2857 & 1000 & 2.5 & 3 & 2 & 1 & 8.5 & 2.98 \\
\hline 3 & 3107 & 1250 & 2.5 & 1 & 3 & 2 & 8.5 & 3.42 \\
\hline
\end{tabular}

Tabel 1. menunjukkan bahwa proses pengadukan atau pencampuran pakan ternak sangat berpengaruh pada berat bahan dan laju putaran mesin agar mendapatkan hasil efisiensi pada alat pencampur pakan ternak.

\section{Efisiensi Alat Pengaduk Pakan Ternak}

Ket : Menghitung Efisien pada Pengujian 1 sebagai berikut.

Pengujian 1:

$$
\begin{aligned}
\mathbf{E f f}= & \frac{\text { Jumlah }(\mathrm{kg}) \times \text { Poros }(\mathrm{Rpm})}{\text { Putaran }(\mathrm{Rpm})} \\
= & \frac{8.5 \mathrm{~kg} \times 750 \mathrm{Rpm}}{2607 \mathrm{Rpm}} \\
= & 2.45 \mathrm{Rpm} / \mathrm{kg}
\end{aligned}
$$

Menghitung Efisien pada Pengujian 2 sebagai berikut.

Pengujian 2 :

$$
\begin{gathered}
\text { Eff }=\frac{\text { Jumlah }(\mathrm{kg}) \times \text { Poros }(\mathrm{Rpm})}{\text { Putaran }(\mathrm{Rpm})} \\
=\frac{8.5 \mathrm{~kg} \times 1000 \mathrm{Rpm}}{2857 \mathrm{Rpm}} \\
=2.98 \mathrm{Rpm} / \mathrm{kg}
\end{gathered}
$$

Menghitung Efisien pada Pengujian 3 sebagai berikut.

Pengujian 3 :

$$
\begin{aligned}
& \text { Eff }= \frac{\text { Jumlah }(\mathrm{kg}) \times \text { Poros }(\mathrm{Rpm})}{\text { Putaran }(\mathrm{Rpm})} \\
&= \frac{8.5 \mathrm{~kg} \times 1250 \mathrm{Rpm}}{3107 \mathrm{Rpm}} \\
&=3.42 \mathrm{Rpm} / \mathrm{kg}
\end{aligned}
$$

Dari perhitungan diatas dapat disimpulkan bahwa saat proses pencampuran pakan ternak dengan menggunakan putaran tinggi akan menghasilkan hasil yang baik. Hasil ini berbanding terbalik dengan pengadukan pakan ternak menggunakan putaran rendah, dikarenakan saat pengadukan dengan putaran rendah pengaduk pakan ternak tidak efisien. Hal ini digambarkan pada efisiensi pencampuran pakan ternak.

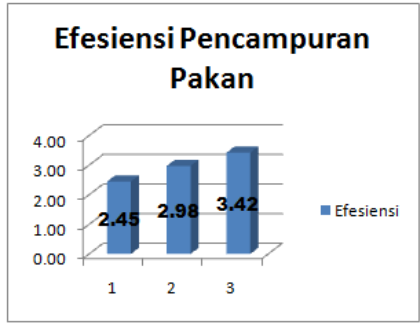

Gambar 4.6. Grafik Efesiensi Pencampuran Pakan Ternak

Dari gambar grafik 4.6 menunjukan hasil efisiensi pencampuran dengan putaran pertama poros $750 \mathrm{Rpm}$ menghasilkan $2.45 \mathrm{Rpm} / \mathrm{kg}$ pada putaran ke dua poros 1000 Rpm menghasilkan 2.98 $\mathrm{Rpm} / \mathrm{kg}$ sedangkan pada putaran ke tiga poros $1250 \mathrm{Rpm}$ menghasilkan $3.42 \mathrm{Rpm} / \mathrm{kg}$.

\section{KESIMPULAN}

Berdasarkan modifikasi alat "Rancang Bangun Mesin Pengaduk Pakan Ternak", maka dapat disimpulkan beberapa hal diantaranya :

1. Mesin ini dapat dapat membantu perkembangan di sektor peternakan, terutama dalam bidang pengadaan pangan yaitu pengadukan pakan ternak.

2. Jadi hasil efisiensi pencampuran dengan putaran pertama poros 750 Rpm menghasilkan $2.45 \mathrm{Rpm} / \mathrm{kg}$ pada putaran ke dua poros $1000 \mathrm{Rpm}$ menghasilkan 2.98 $\mathrm{Rpm} / \mathrm{kg}$ sedangkan pada putaran ke tiga poros $1250 \mathrm{Rpm}$ menghasilkan $3.42 \mathrm{Rpm} / \mathrm{kg}$.

3. Hasil proses perhitungan dapat disimpulkan bahwa saat proses pencampuran pakan ternak dengan menggunakan putaran tinggi akan menghasilkan hasil yang baik. Hasil ini 
berbanding terbalik dengan pengadukan pakan ternak menggunakan putaran rendah, dikarenakan saat pengadukan dengan putaran rendah pengaduk pakan ternak tidak efisien.

\section{DAFTAR PUSTAKA}

Ahmad, 2010, Manajemen Pengelolaan Limbah Pertanian untuk Pakan Ternak Sapi, Kementerian Pertanian, BPPT NTB

Anggorodi, 1985. Pedoman Analisis Potensi Wilayah Penyebaran dan Pengembangan Peternakan. Balai Penelitian Ternak dan Direktorat Bina Penyebaran dan Pengembangan Peternakan Direktorat Jenderal Peternakan, Jakarta.

Badan Pelaksan Penyuluhan Pertanian, perikanan dan Kebutanan Sukabumi. http://bp4kkabsukabumi.net/index.php/Search.html ?searchword=singkong+dan+racun. 31 Januari 2012.

CV. REKATEHNIKNDO (Rekatehnikindo.2015).

Djajanegara, 1999. Local Livestock Feed Resource. In : Livestock Industries of Indonesia Prior to the Asia Financial Crisis. RAP Publication 1999/37. Bangkok FAO Regional Office for Asian and the Pacific.

Djayanegara, 1983. Pemanfaatan limbah pertanian sebagai pakan ruminansia pada peternak rakyat di Kecamatan Rengat Barat Kabupaten Indragiri Hulu. J. Peternakan

Harsono, H. 2002. Pembuatan Silika Amorf dari Limbah Sekam Padi. Jurnal Ilmu Dasar. Vol. 3(2), hal 98-103.
Jayasurya, 2002. Principles of Rations Formulation for Ruminant. Di dalam: Development and Field Evaluation of Animal feed Supplementation Packages. IAEA-TECDOC-1294. Austria. IAEA.

Joomjantha S. 2007. Effect of Intercropping of Cassava Cultivation on Biomass Yield, and Chemical Compositions. Tropical Feed Resources Research and Development Center. Department of Animal Science,Faculty of Agriculture, Khon Kaen University: Khon Kaen, Thailand

Parakkasi, A. 1999. Ilmu Nutrisi dan Makanan Ternak Ruminansia. UI-Press. Jakarta.

Rani, 2010. Mengenal jenis-jenis pangan dan palawija. Mei 2012.

Sukria, 2009. Sumber dan ketersediaan bahan baku pakan di Indonesia.Bogor. IPB Press.

Sutanmuda.wordpress.com/2008/07/22/budidaya rumput gajah untuk pakan ternak

SYAMSU, 2007. Karakteristik Pemanfaatan Limbah Tanaman Pangan sebagai Pakan Ternak Ruminansia Pada Peternakan Rakyat di Sulawesi Selatan. Seminar Nasional Asosiasi Ahli Nutrisi dan Pakan Indonesia.Yogyakarta, 26 - 27 Juli 2007.

Tillman, 1989. Ilmu makanan ternak dasar. Gajah Mada University Press, Yogyakarta.

Utomo, 2011 Peta potensi wilayah sumber bibit sapi potong lokal dan rencana pengembangannya.http://www.ditjennak.go.id/publi kasi\%5Cpotens \% 20bibit.pdf. (6 Juni 2011).

Wiryosuhanto. 1987. Petunjuk Teknik Penggunaan Limbah Pertanian dan Teknologi Pengolahannya Untuk Pakan Ruminansia. Direktorat Bina Produksi Peternakan Departemen Pertanian. 